\title{
Current State of Anaerobic Digestion of Organic Wastes in North America
}

\author{
Jessica L. Linville ${ }^{1}$ - Yanwen Shen ${ }^{1} \cdot$ May M. $\mathrm{Wu}^{1} \cdot$ Meltem Urgun-Demirtas ${ }^{1}$
}

Published online: 1 October 2015

(C) Springer International Publishing AG (outside the USA) 2015

\begin{abstract}
With the large volumes of organic waste produced in the USA each year (78.7 million tons of organic municipal solid waste, 335 million tons of animal manure, and 130 million tons of biosolids), there is potential to develop a viable biogas industry via anaerobic digestion $(\mathrm{AD})$ that can boost the economy and provide a reliable, distributed source of renewable energy while reducing greenhouse gas emissions. $\mathrm{AD}$ is a better practice for organic waste management than the current practice of landfilling or incineration. Since 2013, US public policy and market conditions have been looking increasingly favorable for the development of $A D$ of organic waste. Some of the main barriers to commercialization of an $\mathrm{AD}$ industry include highly variable organic waste characteristics and volume, process economics, biogas cleanup requirements, policy, and public acceptance. This paper discusses new technologies to overcome these barriers with case studies from successful companies in the USA.
\end{abstract}

Keywords Biogas - Anaerobic digestion - Organic waste . Food waste $\cdot$ Manure $\cdot$ Biosolids $\cdot$ Renewable energy . Fertilizer

\section{Introduction}

Methane is a potent greenhouse gas (GHG) and a valuable source of energy $[1,2]$. Biogas systems capture methane

This article is part of the Topical Collection on Sustainable and Renewable Fuels

Meltem Urgun-Demirtas

demirtasmu@anl.gov

1 Energy Systems Division, Argonne National Laboratory, $9700 \mathrm{~S}$ Cass Avenue, Lemont, IL 60439, USA produced from anaerobic digestion (AD) of organic materials and utilize it to create energy (e.g., electricity, heat, and vehicle fuel) $[3,4]$ and additional byproducts such as nutrient rich soil amendments and fertilizers [1]. Studies have shown that the digestate is less odorous, having lower density of pathogens, and enriched nutrients compared to raw waste [3]. Historically, $\mathrm{AD}$ was focused on waste management with the financial benefits of bio-power being a secondary goal [5]. Therefore, it will be beneficial to recover the large sources of suitable organicrich waste materials produced in the USA for biogas production and convert them into energy and valuable products $[1,6-8]$.

Current waste management practices release large amount of methane into the environment. In 2013, landfills were the third largest source of $\mathrm{CH}_{4}$ emissions in the USA (114.6 million metric tons of $\mathrm{CO}_{2}$ equivalent $\left(\mathrm{MMT} \mathrm{CO}_{2} \mathrm{e}\right)$ ) [9]. As the largest portion of organic waste sent to landfills [10] and the highly biodegradable nature of the waste [11], food waste (FW) is usually the dominant contributor to considerable amount of uncontrolled GHG releases from landfills [9]. Additionally, in the USA in 2013, manure management from dairy cattle, swine, and beef cattle operation was the fifth largest source of $\mathrm{CH}_{4}$ emission (61.4 MMT $\left.\mathrm{CO}_{2} \mathrm{e}\right)$ and the 14,780 wastewater treatment plants (WWTPs) was the seventh largest source of $\mathrm{CH}_{4}$ emissions (15.0 $\mathrm{MMT} \mathrm{CO}_{2} \mathrm{e}$ ) [9]. Together, these categories account for $29.2 \%$ of total $\mathrm{CH}_{4}$ emission [9].

Comparisons of the economic and environmental impacts of different FW management methods (landfilling, composting, FW disposer to WWTPs, curbside collection for direct $\mathrm{AD}$, and curbside collection for $\mathrm{AD}$ at WWTPs) determine that direct AD had the lowest total $\mathrm{CO}_{2} \mathrm{e}$ emissions compared to the other methods $[4,12,13]$. Nationwide AD systems are projected to reduce cumulative energy consumption by nearly 15 million TJ and reduce GHG emissions by 7.2 billion tons $\mathrm{CO}_{2} \mathrm{e}$, over a 50 -year period 
[14]. Developing a viable US biogas industry can boost the economy and provide a reliable, distributed source of renewable energy while reducing GHG emissions, improve air quality, and reduce dependence on foreign oil. This paper evaluates the public policy changes necessary to have a successful $\mathrm{AD}$ industry, the current state of AD in the USA and abroad, and a few of the technical barriers to AD with case studies from North America.

\section{Public Policy}

Digestion of organic waste is environmentally friendly; however, environmental regulations have not always been supportive, introducing barriers from air, water, and biosolids permitting requirements and discouraging organic waste-toenergy via AD [15]. Since 2013, US market conditions have been looking increasingly favorable for $\mathrm{AD}$ of organic waste [16]. Although conditions still vary state-to-state, advances in technological application, economic and environmental implications of FW disposal, and favorable legislative developments are driving local, state, and national investment interest $[16,17]$. Public policies used for commercial development of $\mathrm{AD}$ can restrict competing technologies' usage or promote AD technologies for waste disposal and biofuel production. The first group can be represented by various landfill bans, landfill taxes, more strict environmental regulations of other biofuel production processes, location restrictions, environmental/agricultural regulations of feedstock production, and others [14]. The second group of policies focuses on creating awareness of AD technology overall and its benefits and eliminating barriers for commercialization such as promotion of usage of its desired products and promotion of separate collection of waste [14].

Public policy promoting AD technology includes the recent changes to the Renewable Fuel Standard (RFS2) by the US EPA to include biogas as a cellulosic and advanced fuel to meet renewable volume obligations (RVO) [18]. This action promotes production of biogas for transportation and generation of Renewable Identification Numbers (RINs), creating a market for $\mathrm{AD}$ of organic waste by overcoming the economic barriers to digester operation and biogas production. Even with the full utilization of biogas, WWTPs would not be able to meet the estimated 21 billion gallons of cellulosic biofuel RVO by 2022 [8] which will allow for an expanded market into other organic waste utilization such as food waste and manure.

Multiple changes in policies are needed to promote further $\mathrm{AD}$ development such as decreased overall capital intensity of biogas production, promotion of biogas usage, decreased biodegrable municipal solid waste (MSW) heading to landfills, promotion of further basic and applied research to improve the $\mathrm{AD}$ process, and promotion of separate collection of MSW [14]. A US feed-in-tariff program for AD could dramatically improve the viability of AD because it would provide stability and predictability in guaranteeing sufficient returns on investment [19]. Perhaps the least controversial mandate that local governments could adopt to support $\mathrm{AD}$ technology is to require consumers to perform "source separation" of their wastes which requires organic waste to be separated from nonorganic waste by end-consumers before it is collected by waste services [19]. Cities such as Madison, WI and San Francisco, CA have adopted zero waste goals as part of their waste management strategies which restricts mass incineration and landfilling [4, 20, 21]. San Jose, CA plans to divert $80 \%$ of its recyclable or organic waste from landfills [14]. Connecticut and Massachusetts requires that each commercial food wholesaler or distributor, industrial food manufacturer or processor, supermarket, resort, or conference center meeting certain requirements ensure that their food waste is recycled at an authorized composting facility [17]. Vermont's FW ban includes residential generators with source separation by 2017 [17]. New York and Wisconsin have financial incentive programs which provide financial assistance to small businesses seeking to implement sustainable energy production technologies [14]. Twenty-five states also have bans on leaves, grass, and/or brush from landfill disposal [22].

\section{Current State}

$\mathrm{AD}$ technology is better established and more common in Europe than in the USA [14, 17]. Countries such as Germany, Denmark, and UK found a successful public policy solution for further development of $\mathrm{AD}$ technology. Landfill taxes, landfill bans, and various separate collection systems for organic waste are essential elements of their public policy $[14,19]$. Many European governments also provide direct financial assistance to renewable energy producers [19]. In Europe, there are $244 \mathrm{AD}$ plants with a treatment capacity of almost $8 \mathrm{MMT} / \mathrm{year}$ of organic fraction of municipal solid waste (OFMSW) which represents about $5 \%$ of the biodegradable waste generated across Europe [23].

Biogas production from manure has been practiced successfully for many years with 175-240 AD systems currently utilizing organic waste in the USA, generating 541 million $\mathrm{kWh}$ of energy and reducing methane emissions by approximately 1.2-2 MMT $\mathrm{CO}_{2} \mathrm{e}[1,19]$; however, many of these facilities are farm-scale small operations [14, 19]. There are also 1484 WWTPs with AD technology; however, less than $10 \%$ of those plants utilize biogas for energy production [24]. Shen et al. produced a thorough review of the state of US biogas utilization at WWTPs [8].

The US government has set a target for $20 \%$ of the electricity consumed by Federal agencies to be renewable energy by 2020 [1]. Estimates show that with proper support, more than 11,000 additional biogas system could be added in the 
USA with approximately 8000 utilizing livestock manure, 500 utilizing landfill gas, and 2500 utilizing sewage sludge from WWTPs which could produce enough energy to power more than 3 million American homes and reduce methane emissions equivalent by 4-54 MMT $\mathrm{CO}_{2} \mathrm{e}$ through fossil fuel replacement in 2030 [1]. Furthermore, if $50 \%$ of the FW generated annually was anaerobically digested, it could produce enough energy to power more than 2.5 million addition American homes for a year [16].

\section{Feedstock Assessment}

$\mathrm{AD}$ works for many types of organic waste including $\mathrm{FW}$, animal manure, and sewage. In 2012, Americans discarded 149 MMT of MSW in landfills or by incineration, of which approximately 31.5 MMT was FW and 22.1 MMT was paper and paperboard (Fig. 1) [10]. With less than $5 \%$ of discarded FW being recovered, landfilling or incineration is an ineffective and unfeasible solution due to space limitations in the USA and high moisture content of FW increases energy consumption during combustion [7]. Furthermore, incineration of MSW generates a variety of air pollutants that contribute to impacts such as climate change, smog, acidification, and adverse health effects [25]. Of the discarded MSW, an additional 13.0 MMT was yard waste and 12.2 MMT was wood (Fig. 1) [10]. Together, these categories account for nearly $53 \%$ of discarded MSW. The USDA estimates that more than 335 MMT of animal manure is produced annually from the US livestock industry [26] and WWTPs produce approximately 130 MMT of sewage sludge annually, and this volume will increase with the growing population and stringent discharge regulations (Fig. 1) [8] .

\section{Overcoming Barriers to AD of Organic Waste}

$\mathrm{AD}$ is a better practice for organic waste management by effectively decreasing the volume of waste, producing an alternative energy source as attributed to high solid destruction efficiency (up to $90 \%$ ) with high methane yields [27-29]. Table 1 lists various types of waste providing the highest methane yield [30-32]. This leads to decreased site space and reduced carbon footprint. A bench-scale pilot study conducted by East Bay Municipal Utility District in California reported FW had three times the methane production potential of sewage sludge [33].

Table 2 summarizes recent $\mathrm{AD}$ installations for $\mathrm{FW}$, manure, or other organic waste in North America which will be used as case studies below. A better understanding of the key design and operating parameters and their variation during $\mathrm{AD}$ of FW will undoubtedly contribute to its future successful application. Collaboration is needed between the waste generators and the waste managers to help address these barriers.

\section{Solids Content}

$\mathrm{AD}$ is practiced in two broad categories of solid content: highsolids AD (HSAD or dry digestion) with typical total solids (TS) content greater than $25 \%$ and low-solids AD (LSAD or wet digestion) with a TS content of less than $15 \%[14,19,34]$. A HSAD system leads to smaller,
Fig. 1 Organic waste for potential use in anaerobic digesters (data sources: $[8,10$, 26])

\section{Million metric wet tons per year}

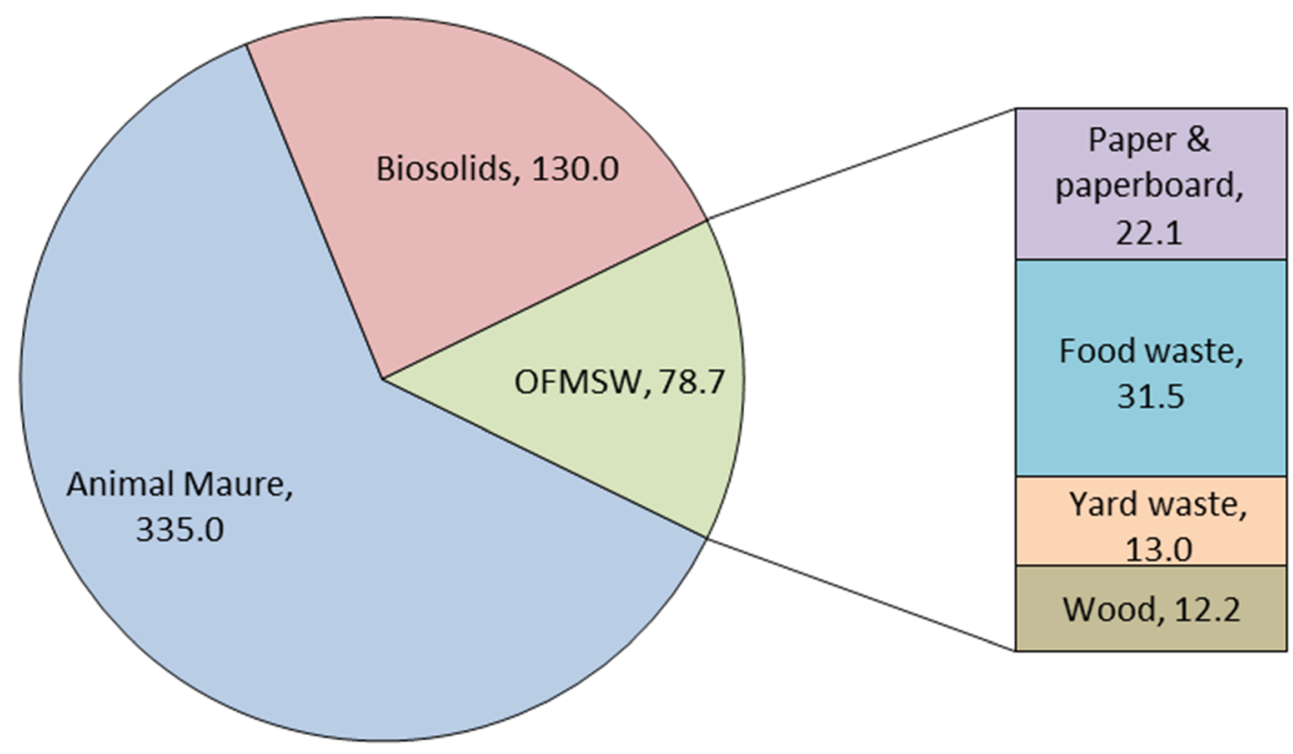


Table 1 Biogas yield and specific biomethane potential of various feedstocks (data source: [30-32])

\begin{tabular}{lll}
\hline Feedstock & Biogas yield & Specific biomethane potential \\
\hline & $\begin{array}{l}\text { ( } \mathrm{m}^{3} \text { gas/ ton } \\
\text { wet mass })\end{array}$ & $\left(\mathrm{m}^{3} \mathrm{CH}_{4} /\right.$ ton VS $)$ \\
Fats, oil and grease & 961 & 1250 \\
Bakery waste & 714 & 476 \\
Rapeseed cake & 660 & 396 \\
Cereal grains & 620 & 389 \\
Molasses & 315 & 308 \\
Oat hull & 283 & 190 \\
Raw glycerol & 250 & 185 \\
Corn stover & 217 & 180 \\
Corn silage & 200 & 340 \\
Grass silage & 180 & 310 \\
Food waste & 144 & 289 \\
Poultry manure & 140 & 280 \\
Sugar beet & 130 & 350 \\
OFMSW & 120 & 500 \\
Brewery waste & 118 & 313 \\
Sweet sorghum & 108 & 291 \\
Potato pulp & 80 & 336 \\
Corn thin stillage & 70 & 600 \\
Alfalfa silage & 70 & 300 \\
Swine manure & 28 & 250 \\
Dairy manure & 25 & 210 \\
\hline
\end{tabular}

and thus less costly, digesters; however, more expensive pumps are needed to move denser material. HSAD digesters also benefit from producing little to no centrate (reject water stream from dewatering of final digestate) due to high initial solids content [35]. LSAD systems have much better mixing, thus increases the degree of digestion; however, they require larger reactor volumes, more energy input and more process water [34]. TS of FW are typically $30 \%$; therefore, water must be added for most AD operations [5, 12]. Due to water usage constraint and the transition of old compositing facilities to AD facilities, dry systems have become standard in Europe, making up $60 \%$ of the single-stage digester capacity installed [14].

Additionally, source separated versus mixed food waste plays an important role in AD facility design. Mixed-waste collection requires considerable pretreatment of the waste at the $\mathrm{AD}$ facility to remove the nonorganic materials such as metal, glass, plastic, and rock-like debris [19]. Nonorganic materials can lead to up to $60 \%$ decrease in gas yield, because of equipment malfunctions and sedimentation buildup in LSAD units increasing maintenance costs [19, 23, 29, 34]. Source separation is often more effective than separation at the plant which reduces the likelihood of breakdowns in $\mathrm{AD}$ technology [19].

\section{Case Study 1}

The Monterey Regional Waste Management District facility was the first operating SMARTFERM system in North America which was completed in February of 2013 (Table 2) [35]. The system converts up to $5000 \mathrm{t}$ per year (TPY) of organic waste into biogas which provides power and heat in a $100 \mathrm{~kW}$ combined heat and power (CHP) unit and produces $2200 \mathrm{TPY}$ of compost for local farms. Zero Waste Energy, LLC (ZWE) designed the facility utilizing SMARTFERM $^{\circledR}$ HSAD proprietary technology $[14,35]$ which does not require the removal of nonorganic materials reducing costs. Under batch $\mathrm{AD}$, the organic waste is finely sprayed with conditioned process waster containing thermophilic microorganisms ("percolate") that decomposes the waste and produces biogas. The percolate is pumped in a closed loop between the digesters and the heated percolate tanks located beneath the dry digester [35]. Zero Waste Energy offers two approaches to turn the digestate into salable compost; in-vessel composting (IVC) system and Lane Turner (LT) Technologies which mature the compost, reduce odor, and remove ammonia from the digestate [35]. The San Jose Zero Waste facility is the largest dry AD facility in the world. The facility treats approximately 90,000 TPY of commercial organic waste and produces 34,000 TPY high-quality compost (Table 2). Furthermore, the renewable biogas will provide both on-site power and power for sale with the 1.6 MW electrical output. The South San Francisco ZWE project was the first US SMARTFERM dry AD facility to convert 11,200 TPY food and green waste into 100,000 diesel equivalent gallons (deg) of low carbon compressed natural gas (CNG) fuel per year, enough to fuel 10 collection vehicles and will also produce $5000 \mathrm{TPY}$ of compost (Table 2).

\section{Organic Waste Characteristics}

The high energy content of FW could significantly improve the biogas yields of co-digestion systems [6]. FW has high volatile solids (VS) to TS percent of over $80 \%$ and digests well with a high VS reduction of over $80 \%$ [15]. Organic waste rich in easily biodegradable matters such as carbohydrates and lipids can accelerate hydrolysis to provide more soluble substrates for subsequent acidogenic and methanogenic processes [28]. However, the high TS, low pH, and chemical composition of mixed $\mathrm{FW}$ such as $\mathrm{C} / \mathrm{N}$ ratio or ammonia can pose challenges for $\mathrm{AD}$ operation [3, 36-38]. Among these parameters, the $\mathrm{C} / \mathrm{N}$ ratio is one of the important parameters in $\mathrm{AD}$, with an effective $\mathrm{C} / \mathrm{N}$ ratio of $15-20$ [38]. Furthermore, various cations, including $\mathrm{Ca}^{+}$and $\mathrm{K}^{+}$, are required for microbial growth but can become inhibitory at higher concentrations $[28,37,39,40]$. Lipids can also be toxic to anaerobic organisms; oleic and stearic acids can inhibit microbial activity at concentrations of $1.0 \mathrm{~g} / \mathrm{L}$ [38]. Other 
荡|

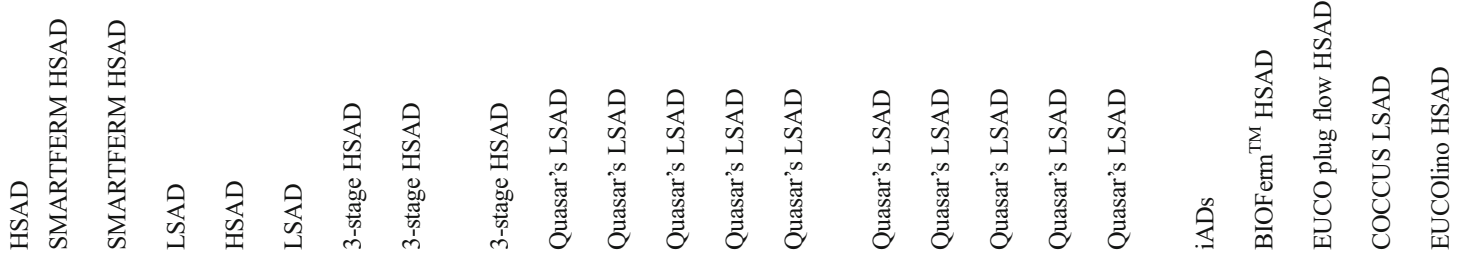

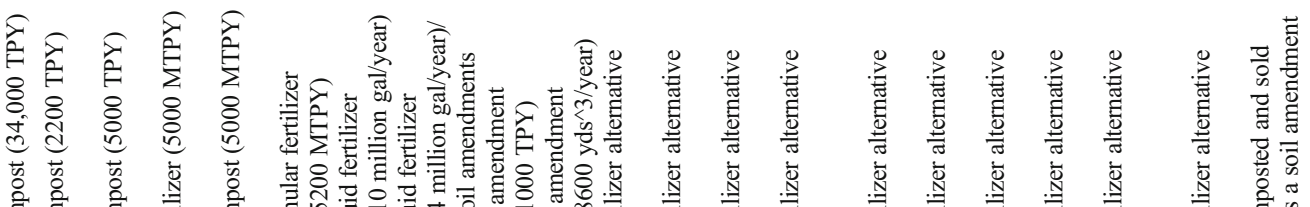

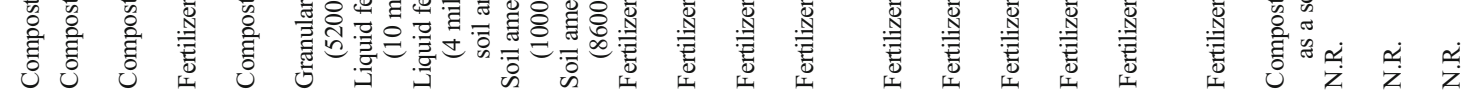

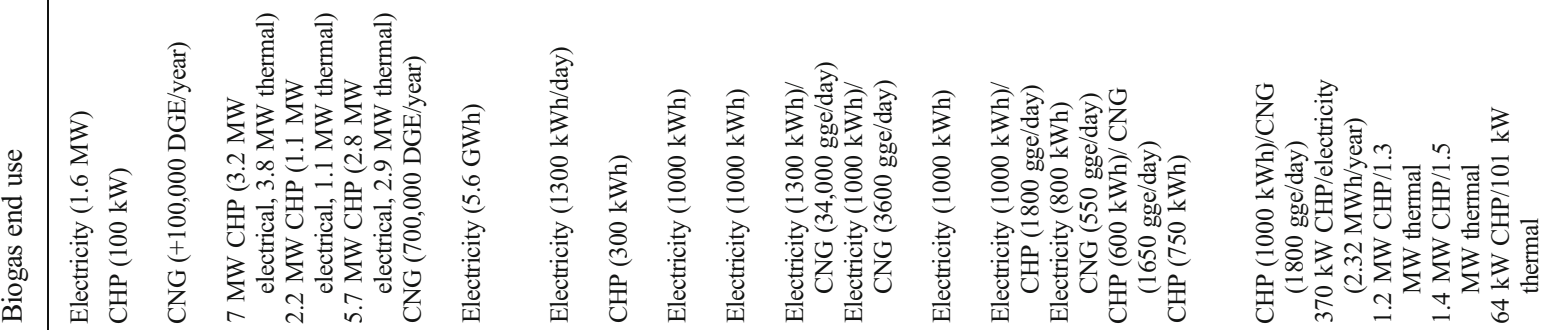

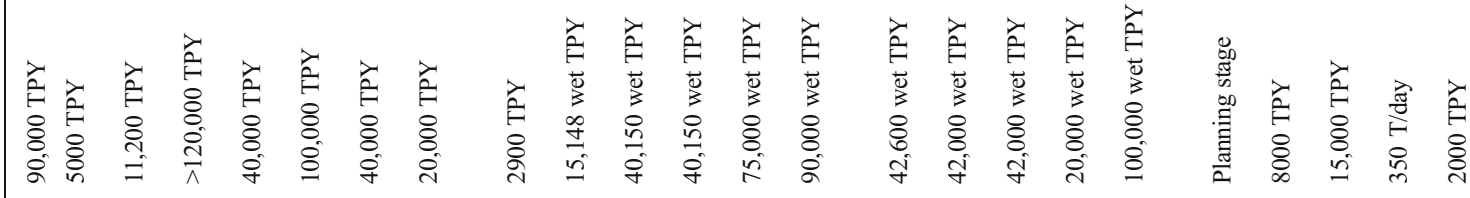

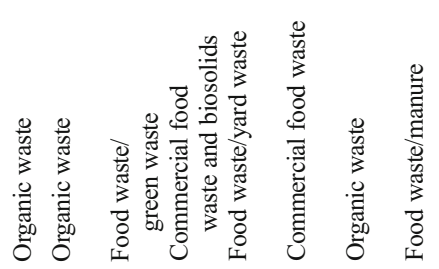

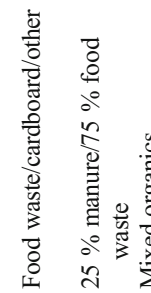

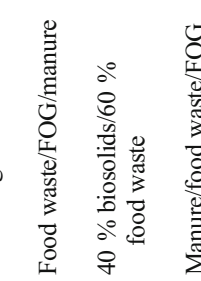

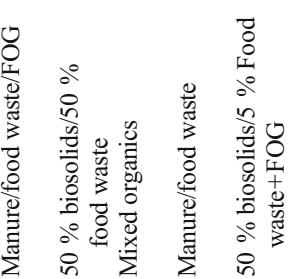

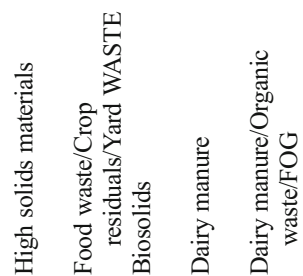

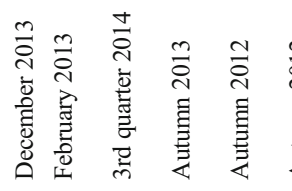

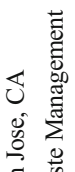

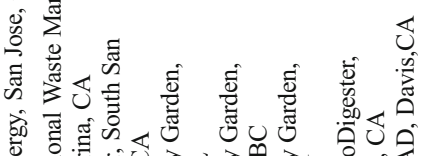
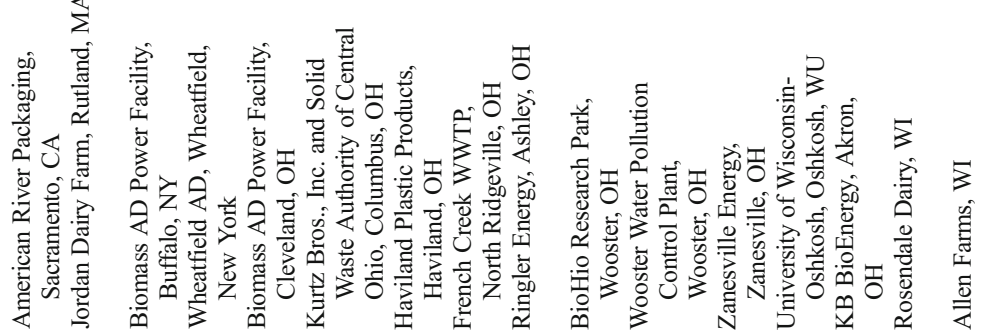
inhibitory substances to AD of FW include volatile fatty acids and hydrogen sulfide [7]. Significant interactions among various feedstocks can affect microbial community diversity and methanogenic activity [41]. These challenges can lead to drawbacks such as lower methane yield and longer digestion time, hence larger digester installations. Areas of focus for further research include stability of digestion systems receiving a variety of organic wastes and developing more sophisticated organic loading rates to enable more aggressive loading while maintaining stability [15].

Currently, co-digestion is the general way for increasing the methane yield and production during $\operatorname{AD}[3,4,32,39,42]$. The attractive co-digestion feedstock includes fats, oil and grease (FOG), FW and food scrap, paper, OFMSW, food/beverage processing waste (e.g., brewery waste and dairy wastewater), energy crops, agricultural residues (rye straw and rapeseed straw), livestock manure, biofuel by-products (e.g., cornethanol stillage, crude glycerol, and spent microalgae), and other high strength waste $[4,8,28]$. The co-digestion of multiple feedstocks could also provide a better environmental practice for reducing methane emissions from unstabilized carbon remaining in the digestate due to poor digestion. Several studies indicate that an additional $1.5-15 \%$ biogas may be produced during the storage and processing of the digested residues because of continuation of anaerobic digestion and centrate supersaturated with dissolved methane [43-47].

\section{Case Study 2}

A LSAD technology developed by quasar can be customized up to 1.15 million gallons with a double membrane roof [48]. Quasar uses a wide range of feedstocks for co-digestion including manure, FW, mixed organics, FOG, biosolids, and high solids materials with a capacity ranging from 15,000 wet TPY which consists of approximately $25 \%$ manure and $75 \%$ food waste at Jordan Dairy Farm in Rutland, MA [49] to 100,000 wet TPY which consists of approximately $50 \%$ biosolids and $50 \%$ other waste streams (FOG, food waste, sugar water, and whey) at the Wooster Water Pollution Control Plant in Wooster, $\mathrm{OH}$ [50] (Table 2). The biogas is utilized to produce $300-1000 \mathrm{kWh}$ of electricity per year. Several of the systems have $\mathrm{CNG}$ production capabilities which can produce 550-3600 gge/day. The AD process also produces a class A or class B biosolids as a fertilizer alternative to increase the economics of the process [51] with the Wooster Water Pollution Control Plant producing 90,000 gal per day effluent with a nutrient value of 10-6-1 (N-P-K) [50].

\section{Design Characteristics}

Design considerations include batch or continuous flow, mixing, temperature, feedstock type, geographic locations, and others [5]. Batch reactors are beneficial due to simple operation and efficient for small volumes; however, disadvantages include larger tank volume required due to the long retention time, the low organic loading rate, and stratification in an unmixed system [34]. The more common method is continuous feeding where feedstock is frequently added to the digester [5]. With continuous operation, the system is at a steady rate and better mixed; however, the digestion efficiency is decreased due to constant effluent removal [34]. The plug-flow reactor and the sequencing batch-reactor combine the advantages of the two extremes [34]. It is necessary to correctly describe the mixing behavior of AD systems in order to accurately predict the system performance, especially at larger scales [2].

AD systems are typically designed to operate in one of two temperature ranges: mesophilic $\left(35-40{ }^{\circ} \mathrm{C}\right)$ and thermophilic $\left(50-55^{\circ} \mathrm{C}\right)[5,23]$. Mesophilic digesters are more common due to lower capital cost and ease of operation. Thermophilic digesters produce more energy with biogas production rates 30-50\% higher compared to mesophilic digestion but are generally more difficult to operate $[5,23]$. Nearly, all US digesters are mesophilic; however, new dedicated food waste digesters tend to use HSAD technology and operate in the thermophilic range which allows for faster processing, reduces the size of the digester, destroys pathogens in the waste, and makes the residual material safe for use as compost and organic soil amendment products [5].

\section{Case Study 3}

The first industrial-scale batch BIOFerm ${ }^{\mathrm{TM}}$ HSAD plant in the USA was installed at the University of WisconsinOshkosh in 2011 (Table 2) [52]. The facility utilizes up to 8000 tons of organics at a time including FW, yard waste, and crop residue. The system produces an average $2.32 \mathrm{MWh} /$ year which can supply as much as $15 \%$ of UWO's electrical need [52]. BIOFerm ${ }^{\mathrm{TM}}$ is capable of recovering energy from almost any kind of organic waste with a moisture content of less than $75 \%$. The system has many advantages over traditional LSAD systems including utilization of large items and contaminated waste streams (non-organics) [52].

COCCUS $^{\circledR}$ is a complete-mix LSAD process for large volumes of low-solids waste (8-12\%) such as manure, biosolids, FW, and energy crops. The COCCUS ${ }^{\circledR}$ process was implemented at Wisconsin's largest dairy, Rosendale, in 2013 where it processes approximately 128,000 TPY of manure. The CHP unit has 1.4 MW electric capacity and 1.5 MW thermal capacity and is expected to produce 11.8 million $\mathrm{kWh}$ of electricity and 12.5 million MMBTU of thermal energy per year [52].

The EUCO ${ }^{\circledR}$ horizontal plug-flow HSAD digester is designed for input materials with a solid content of approximately $17 \%$ [52]. EUCO $^{\circledR}$ liquefies and hydrolyzes solid waste to provide the second-stage digester, such as the COCCUS ${ }^{\circledR}$, with well broken down material where the $\mathrm{AD}$ process is completed. The $\mathrm{EUCO}^{\circledR}$ 
plug flow digester was added to the Akron Wastewater Facility in $\mathrm{OH}$ in 2013 allowing the system to process $100 \%$ of the sewage sludge from the WWTP and creates additional renewable energy (Table 2). The plant consists of three EUCO ${ }^{\circledR}$ plug flow digesters and three COCCUS $^{\circledR}$ complete mix digesters which can handle up to 15,000 TPY of biosolids with maximum TS of $15 \%$. The 2013 expansion included upgrades to the CHP unit which now has 1.2 MW electric capacity and 1.3 MW thermal capacity [52].

The EUCOlino is a small scale HSAD digester that expands the opportunity for energy generation. EUCOlino's versatility allows it to process a wide range of feedstocks with varying solids content. The EUCOlino unit was installed at Allen Farms, in Wisconsin in 2012 to process up to 2000 tons of manure (Table 2). The CHP unit has an electric capacity of $64 \mathrm{~kW}$ and a thermal capacity of $101 \mathrm{~kW}$ with an average annual electricity production of 512,000 kWh [52].

\section{Staged Digesters}

Conventional AD facilities are single stage where hydrolysis through methanogenesis occurs in the same digester [34]. For single stage systems, high strength organic waste may lead to digester overloading, acidification, and reactor upset [6]. Alternatively, two stage AD systems may be less susceptible to system overloading. Two-stage AD systems separate acid fermentation in the first stage from methanogenesis in the second stage for the purposes of optimizing reactor conditions for the different microbial populations [6]. Applications of two-stage AD systems for FW have proven effective for resolving $\mathrm{pH}$ and alkalinity inhibition issues [6] and leads to higher biogas and methane yields [5]. However, increasing the number of stages increases not only capital cost but also operation and maintenance (O\&M) requirements [5].

\section{Case Study 4}

CleanWorld's BioDigesters are a thermophilic, high-rate, three-stage HSAD (up to $50 \%$ solids) continuous system. The first stage hydrolyzes the organic materials. The second stage converts the hydrolyzate to methane. The third stage finishes the methanification, producing leachate with much lower organics than other systems. Each reactor operates under a short retention time, allowing for rapid waste throughput. The system was especially engineered with organic waste in mind, including agricultural residues, commercial food processing waste, and restaurant and supermarket food scraps. In 2012, CleanWorld's first commercial HSAD system was installed at American River Packaging in Sacramento, CA where it converts over 2900 TPY of FW and unrecyclable corrugated material into $474.5 \mathrm{MWh}$ and $1000 \mathrm{TPY}$ soil amendment each year (Table 2). Sacramento BioDigester was built in 2013, utilizes 40,000 TPY of organic waste, and generates 700,000 DGE/year of CNG fuel as well as 10 million gallons of liquid fertilizer and soil amendments [53].

\section{Economic Viability}

AD systems are capital intensive and economic viability heavily depends on revenue models for generating biogas and nutrient rich soil amendments. While average $\mathrm{AD}$ project payback time is 5 to 7 years, some feasibility studies estimate a longer period [4, 16, 54]. Capital costs are high due to the equipment necessary for biogas production and upgrading, in particular biogas upgrading and treatment is one of the major factors determining the feasibility of $\mathrm{AD}[16,29]$. The $\mathrm{O} \& \mathrm{M}$ costs are also considerable at $\mathrm{AD}$ facilities [5]. In order to minimize payback time, all revenue streams of an $\mathrm{AD}$ project should be maximized: converting biogas into electricity for sale, recovering available thermal energy, charging tipping fees for processing organic waste, and selling the digestate as a bio-fertilizer $[4,5,16,54]$. While tipping fees help the process economics, they are generally insufficient to fund an AD system alone. Furthermore, tipping fees for FW must be lower (or subsidized) to incentivize separation of wastes and delivery by private waste haulers [5]. In 2008, the average tipping fee in the USA was $\$ 40.08$ per metric wet ton of waste [22]. Therefore, to be profitable, an AD facility must find customers for its products. The ability to sell excess electricity back to the grid (net metering) is indispensably important in making these facilities profitable $[4,17]$. However, the AD facility may not need all the power produced and the value to sell it can be significantly less than the avoided cost of buying it [15]. The digestate from the AD process has soil enhancement qualities which when applied to growing crops reduces the need for synthetic fertilizers [1, 17]. For example, the quasar LSAD effluent has a nutrient value of 10-6-1 (N-P$\mathrm{K})$ [50]. Furthermore, the centrate is characterized with having high levels of total solids, ammonia, and phosphorus $[55,56]$. Even though the centrate stream normally constitutes only 1 to $2 \%$ of the influent flow, it contributes approximately 15 to $40 \%$ of the nutrient load, such as $\mathrm{N}$ and $\mathrm{P}$ [56]. If not managed properly, the centrate can have a significant impact on treatment performance of WWTPs and increases GHG emissions from WWTPs significantly $[43,44,55]$. However, there are many physical/chemical (struvite precipitation, ammonia recovery process, hot air/steam stripping, etc.) and biological treatment (deammonification by ANAMMOX, nitritation by SHARON ${ }^{\circledR}$ or AT-3, bioaugmentation by $\mathrm{BABE}^{\circledR}$ or InNitri ${ }^{\circledR}$, etc.) technologies that can be used to treat the reject water in a cost-effective manner $[55,56]$.

The legislation relevant to the construction and operation of facilities utilizing $\mathrm{AD}$ of $\mathrm{FW}$, while varying among municipalities and states, fall under four general categories: zoning laws and permitting, demand for biogas, net metering, and access to source separated organic material [17]. 


\section{Case Study 5}

Harvest Power's continuous LSAD (5-15\%) operations are a two-stage system that maximizes biogas production with a thermophilic hydrolysis stage and a mesophilic methanogenic stage. Energy Garden facility in Orlando, FL has the capacity to treat $120,000 \mathrm{TPY}$ and produce $3.2 \mathrm{MW}$ electrical capacity and 3.8 MW thermal capacity. Harvest Power maximizes the economic viability of the AD process with co-digested of $\mathrm{FW}$ from local tourist and resort location with thickened waste activated sludge from the adjacent WWTP. The location of the facility allows them to recuperate operational costs through collection of tipping fees for wastes [5]. The digestate from the digester is separated into a solid and liquid stream. The solids residual is dried to create 5000 MTPY granular fertilizer. The centrate is treated to recover phosphorus by a struvite reactor creating solid struvite fertilizer pellet, and an Anammox sequencing batch reactor is used to reduce the biological oxygen demand and total nitrogen before discharge back to the WWTP [57]. Harvest Power maximizes the economics by selling the finished compost material and struvite to the retail outlets and energy generation through 7 MW CHP unit. The Harvest Energy Garden LSAD facility London, ON has a capacity for 100,000 TPY of organic wastes and can produce 5.7 MW CHP with $2.8 \mathrm{MW}$ electrical capacity and 2.9 MW thermal capacity and 5200 MTPY granular fertilizers. Harvest Energy Garden utilizes HSAD batch operations at the Richmond, BC which has a 40,000 TPY capacity for mixed food and yard waste (20-50\% solids) and utilizes a 2.2 MW CHP unit with 1.1 MW electrical capacity and 1.1 MW thermal capacity and produces 21,000 MTPY of high quality compost [58].

\section{Conclusion}

As landfills reach capacity and awareness of global warming limits the acceptance of solid waste incineration, more demand for sustainable uses of waste will build. The USA would benefit considerably in terms of renewable energy production and environmentally conscientious waste management if $\mathrm{AD}$ technology was more widely utilized. Developing a viable US biogas industry could boost the economy and provide a reliable, distributed source of renewable energy while reducing GHG emissions. Biogas systems have historically been installed to manage waste but can improve profitability for operations through energy and co-product sales, nutrient recovery, and avoided energy costs.

Acknowledgments This work was sponsored by via Sacramento Municipal Utilities by the California Energy Commission of California Government (ARV-10-003-01 SMUD). The submitted manuscript has been created by UChicago Argonne, LLC, Operator of Argonne National
Laboratory (“Argonne”). Argonne, a US Department of Energy Office of Science laboratory, is operated under contract no. DE-AC0206CH11357. The US Government retains for itself, and others acting on its behalf, a paid-up nonexclusive, irrevocable worldwide license in said article to reproduce, prepare derivative works, distribute copies to the public, and perform publicly and display publicly, by or on behalf of the government. The funding source for the work reported here did not have a role in study design, data collection, analysis, data interpretation, writing, or in the decision to publish.

The authors also would like to thank Valentino Tiangco from SMUD and Josh Rapport from Clean Word for providing valuable insight on anaerobic digestion operations.

\section{Compliance with Ethics Standards}

Conflict of Interest Jessica L. Linville, Yanwen Shen, May M. Wu, and Meltem Urgun-Demirtas declare that they have no competing interests.

Human and Animal Rights and Informed Consent This article does not contain any studies with human or animal subjects performed by any of the authors.

\section{References}

1. USDA, USEPA, USDOE. Biogas opportunities roadmap: Voluntary actions to reduce methane emissions and increase energy independence. Washington DC; 2014

2. Van Hulle SWH, Vesvikar M, Poutiainen H, Nopens I. Importance of scale and hydrodynamics for modeling anaerobic digester performance. Chem Eng J. 2014;255:71.

3. Leiva MB, Koupaie EH, Eskicioglu C. Anaerobic co-digestion of wine/fruit-juice production waste with landfill leachate diluted municipal sludge cake under semi-continuous flow operation. Waste Manag. 2014;34:1860.

4. US EPA. Food waste to energy: How six water resource recovery facilities are boosting biogas production and the bottom line. 2014

5. Moriarty K. Feasibility Study of Anaerobic Digestion of Food Waste in St. Bernard, Louisiana: A study prepared in partnership with the Environmental Protection Agency for the RE-Powering America's land initiative. Prepared under Task No. WFD3.1001: National Renewable Energy Laboratory; 2013.

6. Grimberg SJ, Hilderbrandt D, Kinnunen M, Rogers S. Anaerobic digestion of food waste through the operation of a mesophilic twophase pilot scale digester-Assessment of variable loadings on system performance. Bioresour Technol. 2015;178:226.

7. Wang Q, Peng L, Su H. The effect of a buffer function on the semicontinuous anaerobic digestion. Bioresour Technol. 2013;139:43.

8. Shen Y, Linville JL, Urgun-Demirtas M, Mintz MM, Snyder SW. An overview of biogas production and utilization at full-scale wastewater treatment plants (WWTPs) in the United States: challenges and opportunities towards energy-neutral WWTPs. Renewable \& Sustainable Energy Reviews 2015

9. US EPA. National Greenhouse Gas Emissions Data Draft Inventory of U.S. Greenhouse Gas Emissions and Sinks: 1990-2013. Washington, DC: US EPA; 2015.

10. US EPA. Municipal Solid Waste Generation, Recycling and Disposal in the United States: Facts and Figures for 2012. Washington, DC: US EPA; 2012.

11. Levis JW, Barlaz MA. Is biodegradability a desirable attribute for discarded solid waste? Perspectives from a National Landfill 
Greenhouse Gas Inventory Model. Environ Sci Technol. 2011;45: 5470.

12. Parry DL. Analyzing food waste management methods. BioCycle; 2013

13. Levis JW, Barlaz MA. What is the most environmentally beneficial way to treat commercial food waste? Environ Sci Technol. 2011;45: 7438.

14. Naik N, Tkachenko E, Wung R. The anaerobic digestion of organic municipal solid waste in California. Berkeley, California: University of California, Berkeley; 2013.

15. Parry DL. Improving economics of codigestion. BioCycle; 2013

16. RWI. Business Analysis of Anaerobic Digestion in the USA. March 2013: Renewable Waste Intelligence; 2013

17. Fitzgerald L. Anaerobic Digestion of Food Waste in new England Summer 2013 Report. EPA Region 1: US EPA; 2013.

18. USEPA. RFS Renewable Identification Number (RIN) Quality Assurance Program; Final Rule. 40 CFR Part 80. Washington, DC: United States Environmental Protection Agency; 2014.

19. Klinkner BA. Anaerobic digestion as a renewable energy source and waste management technology: What must be done for this technology to realize success in the United States? : UMass Law Review; 2014

20. Zaman AU. A comprehensive review of the development of zero waste management: lessons learned and guidelines. J Clean Prod. 2015;91:12.

21. Yoshida H, Gable JJ, Park JK. Evaluation of organic waste diversion alternatives for greenhouse gas reduction. Resour Conserv Recycl. 2012;60:1.

22. van Haaren R, Themelis N, Goldtein N. The State of Garbage in America. BioCycle; 2010

23. De Baere L, Mattheeuws B. Anaerobic Digestion of the Organic Fraction of Municipal Solid Waste in Europe. Proceedings of the International Conference on Solid Waste. Hong Kong SAR, P.R. China, 2-6 May 2011: Proceedings of the International Conference on Solid Waste. Moving Towards Sustainable Resource Management; 2011, p. 517

24. USEPA. Opportunities for combined heat and power at wastewater treatment facilities: market analysis and lessons from the field. Washington DC: United States Environmental Protection Agency; 2011.

25. US EPA. Air Regulations for Municipal Waste Combustors. US EPA; 2012

26. USDA. Annual report manure and byproduct utilization national program. FY 2005: USDA Annual Report; 2005

27. US EPA. The benefits of anaerobic digestion of food waste at wastewater treatment facilities. Pacific Southwest Region 9; 2008.

28. Bozym M, Florczak I, Zdanowska P, Wojdalski J, Klimkiewicz M. An analysis of metal concentrations in food wastes for biogas production. Renew Energy. 2015;77:467.

29. Lou XF, Nair J, Ho G. Potential for energy generation from anaerobic digestion of food waste in Australia. Waste Manag Res. 2013;31:283.

30. FNR. Basisdaten Biogas Deutschland. Gülzow: Fachagentur Nachwachsende Rohstoffe; 2005.

31. FNR. Basisdaten Biogas Deutschland. Gülzow, Germany: Fachagentur Nachwachsende Rohstoffe; 2005.

31. FNR. Guide to Biogas: From production to use. Eschborn, Germany: Fachagentur Nachwachsende Rohstoffe; 2012.

32. Moody LB, Burns RT, Bishop G, Sell ST, Spajic R. Using biochemical methane potential assays to aid in co-substrate selection for codigestion. Appl Eng Agric. 2011;27:433.

33. Gray DMD, Suto P, Peck C. Anaerobic digestion of Food Waste. Final Report. US EPA Region 9: Funding Opportunity No. EPAR9-WST-06-004; 2008.

34. Ostrem K. Greening Waste: Anaerobic digestion for treating the organic fraction of municipal solid wastes. Columbia University: Earth Resources Engineering; 2004
35. ZeroWaste Energy LLC. SMARTFERM Dry AD Technology. http://zerowasteenergy.com/; Accessed Apr 17, 2015.

36. Chen Y, Cheng JJ, Creamer KS. Inhibition of anaerobic digestion process: a review. Bioresour Technol. 2008;99:4044.

37. Naik L, Gebreegziabher Z, Tumwesige V, Balana BB, Mwirigi J, Austin G. Factors determining the stability and productivity of small scale anaerobic digesters. Biomass Bioenergy. 2014;70:51.

38. Zhang CS, Su HJ, Tan TW. Batch and semi-continuous anaerobic digestion of food waste in a dual solid-liquid system. Bioresour Technol. 2013;145:10.

39. Zhang L, Lee Y-W, Jahng D. Anaerobic co-digestion of food waste and piggery wastewater: focusing on the role of trace elements. Bioresour Technol. 2011;102:5048.

40. Zhang L, Jahng D. Long-term anaerobic digestion of food waste stabilized by trace elements. Waste Manag. 2012;32:1509.

41. Jimenez J, Guardia-Puebla Y, Romero-Romero O, Cisneros-Ortiz ME, Guerra G, Morgan-Sagastume JM, et al. Methanogenic activity optimization using the response surface methodology, during the anaerobic co-digestion of agriculture and industrial wastes. Microbial community diversity. Biomass Bioenergy. 2014;71:84.

42. Lopez RJ, Higgins SR, Pagaling E, Yan T, Cooney MJ. High rate anaerobic digestion of wastewater separated from grease trap waste. Renew Energy. 2014;62:234.

43. Daelman MRJ, van Voorthuizen EM, van Dongen UGJM, Volcke EIP, van Loosdrecht MCM. Methane emission during municipal wastewater treatment. Water Res. 2012;46:3657.

44. Daelman MRJ, Van Eynde T, van Loosdrecht MCM, Volcke EIP. Effect of process design and operating parameters on aerobic methane oxidation in municipal WWTPs. Water Res. 2014;66:308.

45. Borjesson P. Biogas from waste materials as transportation fuelbenefits from an environmental point of view. Water Sci Technol. 2008;57:271.

46. Liebetrau J, Clemens J, Cuhls C, Hafermann C, Friehe J, Weiland P, et al. Methane emissions from biogas-producing facilities within the agricultural sector. Eng Life Sci. 2010;10:595.

47. Hartley $\mathrm{K}$, Lant P. Eliminating non-renewable $\mathrm{CO} 2$ emissions from sewage treatment: an anaerobic migrating bed reactor pilot plant study. Biotechnol Bioeng. 2006;95:384.

48. Quasar Energy Group. Quasar Technology. http://www. quasarenergygroup.com/; Accessed Apr 17, 2015.

49. U.S. Dairy. Case Study - Food waste and third-party partnership. Innovation center for U.S. Dairy; 2013

50. Clemens H. Quasar Energy Group Anaerobic Digesters. Quasar Energy Group; 2013

51. Equatenpk. Sustainable nutrient solutions for this generation... and the next. (Accessed May 29, 2014): http://www.equatenpk.com/ index.html.

52. BIOFerm Energy Systems. BIOFerm Energy Systems. http://www. biofermenergy.com/; Accessed Apr 17, 2015.

53. CleanWorld. CleanWorld. http://www.cleanworld.com/; Accessed Apr 17, 2015.

54. Scano EA, Asquer C, Pistis A, Ortu L, Demontis V, Cocco D. Biogas from anaerobic digestion of fruit and vegetable wastes: experimental results on pilot-scale and preliminary performance evaluation of a full-scale power plant. Energy Convers Manag. 2014;77:22.

55. Constantine TA. North American Experience with centrate treatment technologies for ammonia and nitrogen removal. WEFTEC, Proceedings of the Water Environment Federation; 2006

56. Chandrasekeran P, Urgun-Demirtas M, Pagilla KR. Aerobic membrane bioreactor for ammonium-rich wastewater treatment. Water Environ Res. 2007;79:2352.

57. Sorensen M. Codigestion in Central Florida. BioCycle; 2014, p. 48.

58. Harvest Power. Harvest Power Technology. http://www. harvestpower.com/; Accessed Apr 17, 2015. 